\title{
REVIEW
}

\section{Space Invaders}

\section{Brain Tumor Exploitation of the Stem Cell Niche}

\author{
Justine Sinnaeve, ${ }^{*}$ Bret C. Mobley, ${ }^{\dagger}$ and Rebecca A. Ihrie ${ }^{* \ddagger}$ \\ From the Departments of Cell and Developmental Biology, * Vanderbilt University School of Medicine, Nashville; and the Departments of Pathology, \\ Microbiology, and Immunology ${ }^{\dagger}$ and Neurological Surgery, ${ }^{\ddagger}$ Vanderbilt University Medical Center, Nashville, Tennessee
}

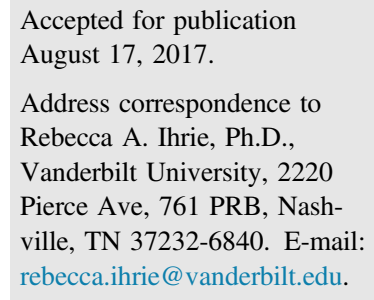

\begin{abstract}
Increasing evidence indicates that the adult neurogenic niche of the ventricular-subventricular zone (V-SVZ), beyond serving as a potential site of origin, affects the outcome of malignant brain cancers. Glioma contact with this niche predicts worse prognosis, suggesting a supportive role for the V-SVZ environment in tumor initiation or progression. In this review, we describe unique components of the V-SVZ that may permit or promote tumor growth within the region. Cell-cell interactions, soluble factors, and extracellular matrix composition are discussed, and the role of the niche in future therapies is explored. The purpose of this review is to highlight niche intrinsic factors that may promote or support malignant cell growth and maintenance, and point out how we might leverage these features to improve patient outcome. (Am J Pathol 2018, 188: 29-38; https://doi.org/10.1016/j.ajpath.2017.08.029)
\end{abstract}

Extensive work during the past decades has demonstrated the existence of two neurogenic niches in the adult mammalian brain: the ventricular-subventricular zone (V-SVZ) and the subgranular zone (SGZ). The cellular constituents, intercellular interactions, and extracellular components of these niches support stem cell maintenance and differentiation. ${ }^{1-3}$ The V-SVZ is the larger of the two niches, and recently there has been increased focus on the role of this niche in highgrade (III and IV) gliomas, the most common primary malignant neoplasms of the adult brain. Interest in the V-SVZ heightened with the emergence of the cancer stem cell theory, which posits that a fraction of cancer cells are self-renewing progenitors at the apex of a cancer cell hierarchy, capable of generating all cell types found in a tumor. ${ }^{4}$ This hypothesis is supported by similarities in gene expression between non-neoplastic stem cells and cancer cells, as well as by their shared capacity for proliferation. In the setting of brain cancer, it has been proposed that neural stem cells of the V-SVZ are cells of origin for brain cancers, although more recent tumor models implicate additional progenitor and mature cells in tumor development (Figure 1). ${ }^{5,6}$ The development of neoplasia after genetic ablation of tumor suppressors and exogenous up-regulation of growth factors in the rodent
V-SVZ have further supported this hypothesis. ${ }^{7}$ Cell of origin notwithstanding, the concept of a stem-like niche within tumors is one with significant therapeutic implications. ${ }^{8,9}$ In addition to the possibility that gliomas originate within the $\mathrm{V}$ SVZ, some tumors may co-opt this niche, taking advantage of an existing system that promotes proliferation and migration of progenitor cells in early development. In support of this hypothesis, radiographic studies show that contact with the $\mathrm{V}-\mathrm{SVZ}$ is a negative prognostic factor for grade IV gliomas. ${ }^{10}$ Given that neural stem cell niche components may enhance glioma initiation, maintenance, and/or recurrence, the interaction between the V-SVZ and tumor cells warrants investigation, and this review will focus on the interplay between

Supported by NIH/National Institute of Neurological Diseases and Stroke grant R01NS096238 (R.A.I.), Department of Defense Idea Development Award W81XWH-16-1-0171 (R.A.I.), Vanderbilt-Ingram Cancer Center (VICC) Ambassadors Award and Discovery Award P30 CA68485 (R.A.I.), a VICC Michael David Greene Brain Cancer Fund gift (R.A.I.), and Ann Faulkenberry Memorial Award SBTA-0001199 from the Southeastern Brain Tumor Foundation (R.A.I.).

Disclosures: None declared.

This article is part of a review series on neural regeneration and developmental biology in health and disease. 


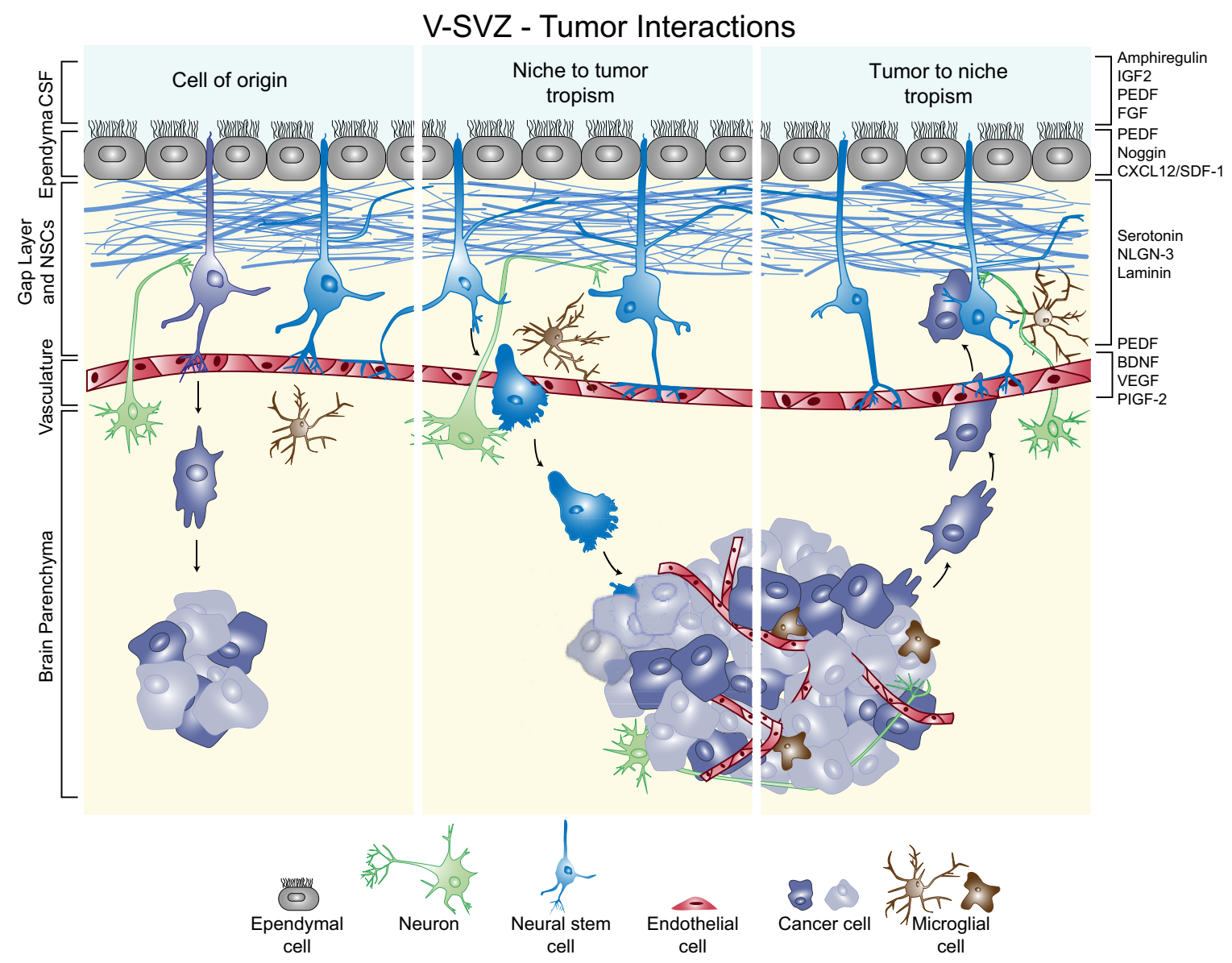

Figure 1 The ventricular-subventricular zone (V-SVZ) niche contains ependymal cells (gray) that contact the lateral ventricle and cerebrospinal fluid (CSF). Neural stem cells (NSCs; blue) have an apical contact with the CSF and a basal contact with the vasculature (red). In the human, astrocytic processes (blue) lie beneath the ependyma. Neurons (green) from the brain parenchyma innervate the niche. Surveying or resting microglia (brown) surveil the niche microenvironment and can become activated in the presence of tumor cells. Three proposed roles of the niche in malignant brain tumors are depicted. Left panel: Neural stem cells may acquire mutations that lead to cancer (purple). Middle panel: Neural stem cells can home toward tumors and eliminate tumor cells. Right panel: Tumor cells can migrate toward the V-SVZ and take up residence in the niche. A subset of factors demonstrated to be involved in these regions and discussed in the text (Direction from the Top: CSF Factors in Normal and Malignant Biology, Local Associations: Cellular Constituents of the Niche, Basal Foundations: Vascular Contact, The Niche as a Refuge) are listed on the right. BDNF, brain-derived neurotrophic factor; FGF, fibroblast growth factor; IGF2, insulin-like growth factor 2; NLGN-3, neuroligin-3; PEDF, pigment epithelium-derived factor; PIGF-2, placental growth factor 2; SDF-1, stromal-derived factor 1; VEGF, vascular endothelial growth factor.

adult stem cell niches and neoplastic cells in this context. We will briefly introduce the V-SVZ niche and summarize the unique features that may provide a selective advantage to cancerous cells.

\section{Distinct Cellular Neighborhoods: The V-SVZ and SGZ}

The two regions of adult neurogenesis, the V-SVZ and the SGZ, contain multiple cell types and specialized contacts, including a prominent vascular component. These features cooperate to maintain an environment permissive to ongoing neurogenesis. The V-SVZ (sometimes referred to as the SVZ or the subependymal zone) is the larger of these two niches and is located immediately adjacent to the lateral ventricles in the cerebrum. The rodent V-SVZ primarily generates interneurons destined for the olfactory bulb, and the early postnatal human brain recapitulates this production of olfactory interneurons. The pediatric human V-SVZ also contributes interneurons to the ventromedial prefrontal cortex via a medial migratory stream and a large population of newly born cells to additional forebrain areas through a structure termed the Arc. ${ }^{11,12}$ In adult humans, robust migration to the olfactory bulb is absent, and V-SVZ neurogenesis appears to be a rare event, although limited contribution of neurons to the neighboring striatum may occur. ${ }^{13,14}$ Adult V-SVZ generation of mature neurons can occur in the setting of brain injury, as has been shown in adult rats after ischemic stroke. ${ }^{15}$

The astrocyte-like neural stem cells (NSCs) of the V-SVZ have a polarity defined by an apical primary cilium immersed in ventricular cerebrospinal fluid (CSF) and a basal vascular contact, resulting in a cytoarchitecture 
reminiscent of embryonic radial glia progenitors. ${ }^{16}$ Ependymal cells within this niche line the lateral walls of the lateral ventricles and also contact the CSF, into which they project motile cilia to aid in CSF flow. ${ }^{17,18}$ Ependymal cell bodies are arranged in pinwheels around the apical contacts of the NSCs (a planar organization not seen in nonneurogenic regions of the ventricular system). ${ }^{16,19}$ NSCs produce rapidly dividing $\mathrm{C}$ cells (alias transit-amplifying cells) that undergo a limited number of divisions to produce neuroblasts, which then migrate out of the niche and eventually generate mature neurons. ${ }^{20}$ The neural stem cell bodies remain in close contact with neuroblasts, whereas their long, radial glia-esque processes contact the blood vessels that supply nutrients and oxygen to the niche.,20 Microglial cells are also found within the niche, as are contacts from neighboring and distant neurons. ${ }^{13,21-24}$

The SGZ is located at the interface of the hilus and dentate gyrus in the hippocampus. ${ }^{2}$ It, too, contains radial-glia-like neural stem cells that produce neurons via transit-amplifying cells. In this niche, the apical portion of the NSC contacts a blood vessel, the highly branched opposite process contacts neuronal processes and glial cells, and the cell body contacts mature granule neurons. ${ }^{25,26}$ In contrast to V-SVZ NSCs, SGZ NSCs do not extend processes into the ventricles to contact CSF, a point of difference between these germinal regions that may be relevant to tumor progression.

\section{V-SVZ Contact and Patient Outcome}

High-grade gliomas, most notably grade IV glioblastomas (GBMs), are defined by their invasive presentation, and a subset of these tumors appears to spread specifically within the ventricular-subventricular zone (alias subependymal spread). ${ }^{27-29}$ V-SVZ spread is evaluated by magnetic resonance imaging in pediatric and adult gliomas and is interpreted as the presence of contrast enhancement and/or abnormally elevated T2-weighted signal within the subependymal region. ${ }^{30-32}$ Although microscopic analysis of this region is uncommon because of the rarity of resections that include the V-SVZ, histologic sections show increased cell density at resection, including cytologically atypical glial cells with enlarged, hyperchromatic, angular nuclei. ${ }^{33}$ Immunohistochemistry of a cell-cycle-associated antigen, Ki-67, can be used to highlight the atypical population, because it is normally infrequently expressed in adult V-SVZ. ${ }^{11,13}$ Preferential spread in the V-SVZ region has been described in high-grade astrocytoma autopsy cases. ${ }^{29}$ Likewise, in pediatric diffuse intrinsic pontine gliomas, contact with the ventricle or V-SVZ correlates with V-SVZ tumor infiltration and nodule formation along the ventricle. ${ }^{34}$ In addition, both isocitrate dehydrogenase wild-type and isocitrate dehydrogenase-mutant GBMs as well as brain metastases have demonstrated such spread through the subependyma. ${ }^{27,28}$ Although isocitrate dehydrogenase-mutant gliomas occur more frequently in the frontal lobe than isocitrate dehydrogenase wild-type tumors, there appears to be no difference between the two groups in V-SVZ contact. ${ }^{35}$ However, the literature on the topic is sparse and warrants further investigation.

Recent evaluation of clinical data indicates that glioblastoma patients whose tumors infiltrate or contact the V-SVZ have worse outcomes. A meta-analysis of multiple studies demonstrated that radiographic contact of GBM with the V-SVZ is associated with significantly decreased overall survival, ${ }^{10}$ independent of extent of tumor resection. ${ }^{36} \mathrm{~V}-\mathrm{SVZ}$ contacting glioblastomas also display earlier recurrence after treatment compared with V-SVZ noncontacting GBMs, ${ }^{10,36}$ and these recurrences are more likely to contact the V-SVZ. ${ }^{37,38}$ Some studies further describe a tendency for V-SVZ contacting glioblastomas to be multifocal at diagnosis ${ }^{36,38,39}$ and to recur after treatment at sites distant from the initial tumor site, ${ }^{39-41}$ although the latter observation is debated. ${ }^{36,42}$ Strikingly, GBM contact with the SGZ has not been found to influence survival, ${ }^{36}$ suggesting that features unique to the V-SVZ contribute to outcome. The prognostic value of V-SVZ contact may be attributable, in part, to cancer cell access to the ventricles and CSF, a feature unique to the V-SVZ niche. However, the V-SVZ and SGZ differ in several additional ways, including the presence of a gap layer in the V-SVZ that is absent in the SGZ and the closer proximity of the V-SVZ to major white matter tracts. At the molecular level, differences between secreted factors in the V-SVZ and SGZ remain poorly defined. Nicheenriched factors may be derived from different cellular sources, present at different levels, or delivered through specific cell-cell contacts. Each of these variations might affect signaling between niche and tumor cells. Cumulatively, these clinical data suggest a possible distinct, aggressive biology of V-SVZ contacting tumors, although attempts to date have failed to identify transcriptional signatures unique to V-SVZ contacting tumors. Only a limited number of candidate signatures have been found, which may not be cancer cell derived. ${ }^{43}$ Alternatively, the impact of V-SVZ contact raises the possibility of niche-derived factors that positively affect one or more aspects of tumor biology, including glioma growth, therapy resistance, dissemination, and immunomodulation.

\section{Direction from the Top: CSF Factors in Normal and Malignant Biology}

Cerebrospinal fluid is produced by the choroid plexus and fills the ventricles. Ciliated ependymal cells, including those in the V-SVZ, help to maintain CSF flow. ${ }^{44,45}$ CSF acts as a protective cushion for the central nervous system and a provider of secreted factors as well as a mechanism for waste removal to maintain homeostasis. The V-SVZ is the only neurogenic niche that directly contacts the ventricles, which contain soluble factors that regulate NSC quiescence and proliferation beyond those traditionally contained in stem cell culture medium (Figure 1). ${ }^{2,46}$ The CSF milieu has been explored most thoroughly in the embryo, but the NSC regulatory factors insulin-like growth factor 2, amphiregulin, and pigment epithelium-derived factor (PEDF), which can promote NSC 
proliferation and self-renewal, have all been detected in adult brain. ${ }^{47-49}$ More important, these factors found in the CSF have also been shown to regulate glioma cell growth and may be a source of growth stimuli to malignant cells. ${ }^{50-52}$

In addition to providing NSCs and cancer cells with soluble factors and signals, the CSF is a potential reservoir for cancer cells and cancer cell-derived secreted factors. Along with radiographic imaging, analysis of CSF cytology obtained via lumbar puncture, although infrequently performed, is used for detection and diagnosis of malignancies. ${ }^{53}$ Tumor DNA can be detected in the CSF of cancer patients, especially in patients whose tumors are located at CSF-brain interfaces. ${ }^{54}$ Glioma cells are also known to release exosomes loaded with RNA species that can be detected in the CSF. ${ }^{55,56}$ The CSF can also serve as an avenue for tumor diffusion in gliomas, although this phenomenon is clinically prominent only in a rare subset of GBMs with primitive neuronal components. ${ }^{57}$ Thus, the CSF may both supply neoplasms with mitogenic cues and harbor tumor cells with the potential to seed additional tumor sites.

\section{Local Associations: Cellular Constituents of the Niche}

NSC interactions with surrounding cells directly influence cell proliferation and stemness. V-SVZ ependymal cells preserve the self-renewal capacity of NSCs, in part by producing PEDF, which promotes symmetric division of NSCs and suppression of differentiation genes. PEDF can similarly suppress glioma stem cell differentiation and promote gliomasphere formation and sex determining region Y-box 2 expression. ${ }^{51}$ Ependymal cells also secrete the bone morphogenic protein inhibitor noggin, which may help maintain glioma cell tumor-initiating capacity, ${ }^{58,59}$ and C-X-C motif chemokine (CXCL) 12, which can induce glioma cell homing to the neurogenic niche (Figure 1). ${ }^{60,61}$

In addition to local cell-derived signals, neuron-derived signals are another component of the V-SVZ niche. Wholemount electron microscopy of murine ventricles has revealed serotonergic axons derived from soma in the raphe nuclei projecting along the ventricular walls amid ependymal microvilli. These cells release serotonergic vesicles that act on the serotonin receptors on NSCs and the choroid plexus. Activation of these receptors on the NSCs results in increased proliferation, whereas serotonin stimulation of the choroid plexus can result in release of fibroblast growth factor into the CSF, a known proliferation stimulant for normal and neoplastic cells. ${ }^{21,62}$ Excitatory cholinergic neurons have been found to increase normal stem cell proliferation in the V-SVZ, and a population of ventral neurons adjacent to the murine V-SVZ directs fate specification through the production of sonic hedgehog. ${ }^{63,64}$ Similarly, cortical neurons projecting to patient-derived glioma xenografts induced an increase in cell proliferation through neuroligin-3 stimulation, suggesting that excitatory neuronal stimulation can regulate glioma growth (Figure 1). ${ }^{65}$
NSCs can also communicate with each other. For example, NSCs in the SGZ generate gap junctions with each other via connexins 43 and 30 . Without these gap junctions, there is a marked reduction in NSC proliferation and number of progeny, reminiscent of the critical role of connexin 43 in radial glia during early cortical development. ${ }^{66,67}$ Glioma cells can also use connexin 43 to establish gap junctions, sometimes with normal astrocytes, that provide unique advantages by facilitating invasion of brain parenchyma. In this context, gap junctions may enhance glioma growth by permitting the exchange of factors, including ATP from astrocyte to glioma cell. ${ }^{68}$ Outside the cell, distinct laminin structures in the V-SVZ, called fractones, are morphologically characterized by thin stalk-like projections with intermittent bulbs. These structures are in close physical contact with the ependyma, endothelia, and NSCs and are hypothesized to serve as reservoirs of mitogens for NSCs. ${ }^{69}$ Glioma cells invading the niche may also contact these stores. Laminin is further observed on the ventricular face of the V-SVZ at the center of ependymal pinwheels, where ependymal cells and NSCs contact each other. ${ }^{70}$ Laminin signaling occurs via the interaction of dystroglycan on ependymal cells with integrin $\alpha 6$ on NSCs and is required for ependymal pinwheel formation and promotion of NSC interactions with blood vessels. ${ }^{70,71}$ Integrin $\alpha 6$ expression is lost as NSCs differentiate. ${ }^{71}$ Glioma cells with stem cell characteristics (enrichment of CD133, oligodendrocyte transcription factor, and Nestin) also express integrin $\alpha 6$. These cells have increased sphere-forming capacity and tumor-propagating abilities relative to integrin-negative or bulk tumor cells. In addition, these cells are closely associated with the perivascular niche. ${ }^{72}$ These data suggest that the rich laminin environment of the V-SVZ may readily support a glioma stem cell population while inhibiting differentiation.

\section{Basal Foundations: Vascular Contact}

The endothelial cells and pericytes comprising the vascular elements of the V-SVZ are closely associated with NSCs (Figure 1). The V-SVZ vasculature consists of a planar plexus with large vessels that branch into smaller ones, unlike cortical vessels, which are smaller and branch more frequently. ${ }^{73}$ Most of the vessels in the brain, including those in the cortex and striatum, are encapsulated by pericytes and astrocytic end feet, which together compose the blood-brain barrier. In the V-SVZ, however, patches of vessels are devoid of this covering. At these sites, NSCs and transit-amplifying cells contact the vasculature, and cell division is observed. ${ }^{71,74}$ Vasculature lacking pericytes and astrocytes appears to be more permissive to exchange of factors, as demonstrated by experiments in rodents showing that dye conjugates carried in the bloodstream can access the V-SVZ niche directly. ${ }^{73}$ These authors also found that soluble growth factors, hormones, nutrients, and oxygen from the blood can infiltrate the CSF via choroid plexus blood vessels, 
supporting a model whereby the V-SVZ niche receives support from the ventricular and vascular aspects of the niche. ${ }^{73}$ Not only do vascular elements regulate access to serum factors, but these cells can also directly stimulate niche signaling. Endothelial cell secretions include PEDF, brainderived neurotrophic factor, placental growth factor 2, and vascular endothelial growth factor. Placental growth factor 2 and vascular endothelial growth factor enhance neuroblast proliferation, whereas PEDF promotes NSC self-renewal and vascular endothelial growth factor improves neuronal survival. ${ }^{75-79}$ To this end, NSCs with access to endothelial cell-cultured medium undergo increased symmetric selfrenewing divisions relative to those cultured with cortical cells. ${ }^{74}$ Direct physical contact with endothelial cells prevents stem cell differentiation and promotes expression of stemness genes (such as Nestin and the Notch effector Hes5) by signaling through ephrinB2 and Jagged $1 .{ }^{80}$ Blood vessels from different regions of the brain can also differentially influence NSC growth. Surprisingly, although both cortical and subventricular endothelial cells can result in an increase in NSC cell number in vitro, cortical endothelial cells do so to a greater degree. ${ }^{79}$

In high-grade gliomas, the blood-brain barrier is often compromised because of the high rate of angiogenesis and tortuous neovasculature. Furthermore, like normal stem cells, cancer stem-like cells tend to cluster near blood vessels. ${ }^{81}$ Incomplete coverage of vessels by support cells, including pericytes, has been observed in gliomas and raises the possibility that glioma cells may receive serum-derived factors that normally influence NSCs. ${ }^{82}$ These cues include growth signals as well as nutrients and oxygen. When medulloblastoma stem-like cells (expressing Nestin, CD133, or both) are co-cultured with endothelial cells, they maintain expression of Nestin and CD133 and form larger spheres. In vivo, coinjection of endothelial cells and medulloblastoma stem-like cells accelerates tumor growth. ${ }^{81}$ Glioma cells have also been shown to be able to assume a pericyte-like phenotype in vivo, including up-regulation of pericyte markers, a close physical association with the vasculature, and a functional role in maintaining tumor growth. ${ }^{83}$ This may be mediated by direct signaling from endothelial cells via the Notch ligand Jagged ${ }^{80}$ because Notch signaling in GBM cells has been shown to promote a pericyte cell phenotype and result in increased tumor vasculature. ${ }^{84}$ In addition, cancer stem cells secrete vascular endothelial growth factor and can promote endothelial cell migration, branching, and tube formation. ${ }^{85}$ Invasion of the V-SVZ, with its rich vascular support, may provide rapid tumor cell access to factors that support aggressive growth.

\section{The Niche as a Refuge}

Features that endow the V-SVZ niche with the ability to support and maintain neural stem cells may also cause it to serve as a refuge for neoplastic cells. In recent years, several factors have been identified that can attract or direct cells to this refuge. Ependymal and endothelial cells in the V-SVZ express the CXCL12 (alias stromal-derived factor 1), which facilitates tumor cell homing to stem cell niches in other cancers. ${ }^{86} \mathrm{GBM}$ patient-derived xenografts were found to coopt CXCL12/C-X-C chemokine receptor 4 signaling to occupy the V-SVZ and reside in the niche (Figure 1). ${ }^{61}$ Orthotopic xenografts of human glioma cells injected into the striatum of immunodeficient mice contained a subset of tumor cells that migrated toward the V-SVZ. Upon integration in the niche, the human cells expressed markers of NSCs and even began to migrate toward the olfactory bulb, suggesting that they were co-opting niche cues and adopting NSC behaviors. Dissection of these tumor cells from the host mouse and subsequent investigation of sphere-forming capacity and tumor initiation indicated that these cells were tumor propagating. ${ }^{61,87}$ Furthermore, glioma cells expressing $\mathrm{C}-\mathrm{X}$-C chemokine receptor 4 found in the $\mathrm{V}-\mathrm{SVZ}$ were shown to be more radioresistant in vitro and in vivo because of signaling through V-SVZ-derived CXCL12. ${ }^{88}$ More recently, conditioned medium from murine V-SVZ was shown to increase diffuse intrinsic pontine glioma cell invasiveness by producing a protein complex, including pleiotrophin, a neurite outgrowth promoting factor. ${ }^{89}$ In vivo interruption of either of these signaling mechanisms, stromalderived factor 1 or pleiotrophin, reduced the number of identifiable cancer cells that reached the V-SVZ. These findings suggest that glioma recurrence and progression may be driven by tumor cell homing to the V-SVZ with subsequent adoption of niche-based, therapy-protective interactions.

A study of glioblastoma patients undergoing tumor resection guided by 5 -aminolevulinic acid provided evidence for glioma cell migration to a neurogenic niche in humans. 5-Aminolevulinic acid is a metabolic precursor of fluorescent porphyrins that can accumulate in cancer cells. ${ }^{90}$ After peripheral injection of 5-aminolevulinic acid, fluorescent cells were detected in the V-SVZ in $65 \%$ of patients. ${ }^{33}$ Histologic analysis of resected tissue confirmed glioma involvement, and driver mutations matching the primary tumor samples were detected. Importantly, the V-SVZ resident cancer cells were capable of generating spheres in vitro and tumors in vivo, confirming that the cells found in the niche can be tumor propagating. ${ }^{33}$ Intriguingly, tumor cells found in the niche tended to be of the mesenchymal transcriptional subtype, regardless of the subtype assigned to the bulk tumor. ${ }^{33,91}$ This finding suggests that either the V-SVZ niche imposes a similar gene expression profile on the glioma cells or a certain cell phenotype is particularly capable of V-SVZ infiltration.

Given that neurogenic niches may harbor cancer cells with tumor-propagating capabilities and increased radioresistance, ${ }^{88}$ some groups have retrospectively examined the impact of targeting the V-SVZ and SGZ with radiation therapy. Although a moderate survival benefit from niche irradiation has been reported, even in the absence of radiographically detectable contact, not all retrospective 
studies of such treatment found a survival benefit. ${ }^{92}$ In fact, a recent study involving 61 patients reported inferior survival when the ipsilateral neural stem cell compartment (V-SVZ and SGZ) received a high dose of radiation (55.2 Gy). ${ }^{93}$ The effect of radiation on noncancerous cells of the stem cell niche warrants consideration when interpreting survival effects. In rodents, it has been shown that either whole brain or V-SVZ targeted radiation can result in sustained loss of cell proliferation and neural precursor production. In patients, necrosis of the V-SVZ can occur after radiation treatment, and this complication correlates with worse performance status. ${ }^{94-96}$ At this time, there are two ongoing clinical trials to investigate the clinical efficacy of explicitly targeting or sparing the V-SVZ during irradiation (NCT02177578 and NCT01478854, respectively). The results of the only prospective clinical trial investigating neural stem cell niche irradiation in $\mathrm{GBM}^{97}$ are promising, reporting significantly improved overall survival when the V-SVZ was irradiated and a trend toward improved survival when the SGZ was irradiated.

\section{Targeted Strikes: NSCs in Therapy}

Although the stem cell niche may support the formation, maintenance, or recurrence of neoplasms, noncancerous NSCs have the potential to serve a therapeutic role. Normal neural stem cells exhibit targeted migration to sites of tumor engraftment and some antitumor effects (Figure 1). Rats receiving xenografts of glioma cells together with NSCs show improved survival in comparison to animals that receive glioma cells only. ${ }^{98} \mathrm{~A}$ survival benefit is maintained in a model of established tumors, when NSCs are administered 3 days after tumor engraftment. Furthermore, NSCs injected into brains millimeters outside the engrafted tumor will migrate toward the cancer cells, encapsulate the tumor, and penetrate the mass, even showing migration toward multifocal tumor sites separate from the bulk. ${ }^{99,100}$ The NSCs do not infiltrate the surrounding brain parenchyma or contralateral hemisphere, suggesting they are specifically targeting the tumor. Migrating NSCs exert an antitumor effect, observed as a reduction in tumor volume 1 to 2 weeks after injection. ${ }^{98,100}$ This effect is observed in multiple brain cancer types, including glioma and medulloblastoma. ${ }^{99}$

The ability of NSCs to seek out tumor cells has inspired a host of studies in which therapies are transported by NSCs for delivery to cancerous cells. Multiple strategies have been used for both the generation of tumor-homing NSCs and therapy delivery. Human neural stem cells and NSCs transdifferentiated from skin fibroblasts have both been shown to successfully target glioma cells in vitro and in vivo. ${ }^{101,102}$ These engineered NSCs induce glioma cell apoptosis via expression of soluble tumor necrosis factor- $\alpha$-related apoptosis-inducing ligand ${ }^{102,103}$ and cytosine deaminase (paired with 5-formylcytosine). ${ }^{104}$ Therapeutic NSCs can promote glioma cell differentiation in addition to apoptosis. ${ }^{101}$ When applied to orthotopic xenograft models in rodents, NSC-delivered therapies have been shown to prolong survival. Importantly, the NSCs retain their ability to target tumor cells after steroid therapy or radiotherapy, both of which are routinely administered during patient care. In addition to effectively reducing tumor burden, these therapies may prove to have fewer off-target effects than currently used pharmaceuticals. Compared with soluble tumor necrosis factor- $\alpha$-related apoptosisinducing ligand administered intravenously or injected into the tumor, tumor necrosis factor- $\alpha$-related apoptosisinducing ligand secreted by NSCs was not detected in organs other than the brain, persisted through 24 hours, and resulted in tumor volume reduction. ${ }^{105}$ This result suggests that NSC-mediated therapies may show pharmacokinetic features preferable to routinely administered chemotherapies. The preliminary investigation of therapeutic NSCs for brain cancers is the basis of an ongoing clinical trial. ${ }^{104}$

\section{Conclusions and Persisting Questions}

The study of neurogenic niches in the adult brain is a rich and active field of research. Beyond the function of these sites as generators of new neurons, emerging data reveal significant effects of neurogenic niches on the behavior of malignant gliomas. Treatment options for these aggressive neoplasms are limited, and patient survival remains dismal; therefore, the potential role of these niches in tumor initiation, maintenance, or recurrence merits further research. Improvements in tumor therapy may include targeting niche factors and disrupting niche-tumor cell interactions, with radiotherapeutic targeting of the V-SVZ representing a first step along this course. As our knowledge of the normal niche continues to expand, newly revealed features may also drive better understanding of tumor cause and therapy response. Areas of interest include the impact of cell-to-cell heterogeneity and lineage priming within normal NSCs on the disease state and the contribution of microglia, the major innate immune population within the brain, to normal and tumor-bearing V-SVZ. Studies from the mouse brain indicate that neural stem cells are spatially diverse, meaning that stem cells from different regions of the V-SVZ produce different progeny. ${ }^{2,63,106-110}$ Examination of spatial differences in tumor-forming or tumor-homing capabilities of heterogeneous NSCs may further inform the design of targeted therapies. Detailed investigations of the role of innate and adaptive immune cells in this niche will also be critical to understanding how these tumors may evade immune detection or targeted immunotherapy approaches (eg, antiprogrammed cell death protein 1/cytotoxic T-lymphocyte antigen-4 agents). Microglia help to define and maintain the neurogenic niche, and recent studies indicate that the V-SVZ resident population is functionally distinct and temporally dynamic, exhibiting an immature phenotype that changes with organismal age. ${ }^{23,111}$ Finally, glioma research 
currently benefits from the ample available patient tissue from primary tumor resections, as well as a plethora of imaging data collected during routine care. One persistent challenge is the integration of molecular information (bulk and single-cell genomic and proteomic approaches) with spatial information obtained from clinical imaging. Recent advances in both the preparation of single-cell suspensions and the collection of high-dimensional data will enhance our ability to map specific populations of cancer and niche cells, providing a better understanding of the impact of V-SVZ niche diversity on tumor behavior. ${ }^{112,113}$

\section{Acknowledgments}

We thank Akshitkumar Mistry, Nalin Leelatian, Allison Greenplate, Gabrielle Rushing, and members of the Ihrie and Irish laboratories (Vanderbilt University) for helpful discussion and critical feedback. We apologize to our colleagues whose work could not be discussed in depth within space limitations.

\section{References}

1. Silva-Vargas V, Crouch EE, Doetsch F: Adult neural stem cells and their niche: a dynamic duo during homeostasis, regeneration, and aging. Curr Opin Neurobiol 2013, 23:935-942

2. Fuentealba LC, Obernier K, Alvarez-Buylla A: Adult neural stem cells bridge their niche. Cell Stem Cell 2012, 10:698-708

3. Bonaguidi MA, Song J, Ming GL, Song H: A unifying hypothesis on mammalian neural stem cell properties in the adult hippocampus. Curr Opin Neurobiol 2012, 22:754-761

4. Reya T, Morrison SJ, Clarke MF, Weissman IL: Stem cells, cancer, and cancer stem cells. Nature 2001, 414:105-111

5. Sanai N, Alvarez-Buylla A, Berger MS: Neural stem cells and the origin of gliomas. N Engl J Med 2005, 353:811-822

6. Zong H, Parada LF, Baker SJ: Cell of origin for malignant gliomas and its implication in therapeutic development. Cold Spring Harb Perspect Biol 2015, 7: a020610

7. Chen J, McKay RM, Parada LF: Malignant glioma: lessons from genomics, mouse models, and stem cells. Cell 2012, 149:36-47

8. Plaks V, Kong N, Werb Z: The cancer stem cell niche: how essential is the niche in regulating stemness of tumor cells? Cell Stem Cell 2015, 16:225-238

9. Gilbertson RJ, Rich JN: Making a tumour's bed: glioblastoma stem cells and the vascular niche. Nat Rev Cancer 2007, 7:733-736

10. Mistry AM, Hale AT, Chambless LB, Weaver KD, Thompson RC, Ihrie RA: Influence of glioblastoma contact with the lateral ventricle on survival: a meta-analysis. J Neurooncol 2017, 131:125-133

11. Sanai N, Nguyen T, Ihrie RA, Mirzadeh Z, Tsai HH, Wong M, Gupta N, Berger MS, Huang E, Garcia-Verdugo JM, Rowitch DH, Alvarez-Buylla A: Corridors of migrating neurons in the human brain and their decline during infancy. Nature 2011, 478:382-386

12. Paredes MF, James D, Gil-Perotin S, Kim H, Cotter JA, Ng C, Sandoval K, Rowitch DH, Xu D, McQuillen PS, Garcia-Verdugo JM, Huang EJ, Alvarez-Buylla A: Extensive migration of young neurons into the infant human frontal lobe. Science 2016, 354: aaf7073

13. Sanai N, Tramontin AD, Quinones-Hinojosa A, Barbaro NM, Gupta N, Kunwar S, Lawton MT, McDermott MW, Parsa AT, Manuel-Garcia Verdugo J, Berger MS, Alvarez-Buylla A: Unique astrocyte ribbon in adult human brain contains neural stem cells but lacks chain migration. Nature 2004, 427:740-744
14. Ernst A, Alkass K, Bernard S, Salehpour M, Perl S, Tisdale J, Possnert G, Druid H, Frisen J: Neurogenesis in the striatum of the adult human brain. Cell 2014, 156:1072-1083

15. Kernie SG, Parent JM: Forebrain neurogenesis after focal ischemic and traumatic brain injury. Neurobiol Dis 2010, 37:267-274

16. Mirzadeh Z, Merkle FT, Soriano-Navarro M, Garcia-Verdugo JM, Alvarez-Buylla A: Neural stem cells confer unique pinwheel architecture to the ventricular surface in neurogenic regions of the adult brain. Cell Stem Cell 2008, 3:265-278

17. Del Bigio MR: The ependyma: a protective barrier between brain and cerebrospinal fluid. Glia 1995, 14:1-13

18. Sawamoto K, Wichterle H, Gonzalez-Perez O, Cholfin JA, Yamada M, Spassky N, Murcia NS, Garcia-Verdugo JM, Marin O, Rubenstein JL, Tessier-Lavigne M, Okano H, Alvarez-Buylla A: New neurons follow the flow of cerebrospinal fluid in the adult brain. Science 2006, 311:629-632

19. Kokovay E, Wang Y, Kusek G, Wurster R, Lederman P, Lowry N, Shen Q, Temple S: VCAM1 is essential to maintain the structure of the SVZ niche and acts as an environmental sensor to regulate SVZ lineage progression. Cell Stem Cell 2012, 11:220-230

20. Doetsch F, Garcia-Verdugo JM, Alvarez-Buylla A: Cellular composition and three-dimensional organization of the subventricular germinal zone in the adult mammalian brain. J Neurosci 1997, 17:5046-5061

21. Tong CK, Chen J, Cebrian-Silla A, Mirzadeh Z, Obernier K, Guinto CD, Tecott LH, Garcia-Verdugo JM, Kriegstein A, AlvarezBuylla A: Axonal control of the adult neural stem cell niche. Cell Stem Cell 2014, 14:500-511

22. Hoglinger GU, Arias-Carrion O, Ipach B, Oertel WH: Origin of the dopaminergic innervation of adult neurogenic areas. J Comp Neurol 2014, 522:2336-2348

23. Ribeiro Xavier AL, Kress BT, Goldman SA, Lacerda de Menezes JR, Nedergaard M: A distinct population of microglia supports adult neurogenesis in the subventricular zone. J Neurosci 2015, 35:11848-11861

24. Dennis CV, Suh LS, Rodriguez ML, Kril JJ, Sutherland GT: Human adult neurogenesis across the ages: an immunohistochemical study. Neuropathol Appl Neurobiol 2016, 42:621-638

25. Seri B, Garcia-Verdugo JM, Collado-Morente L, McEwen BS, AlvarezBuylla A: Cell types, lineage, and architecture of the germinal zone in the adult dentate gyrus. J Comp Neurol 2004, 478:359-378

26. Palmer TD, Willhoite AR, Gage FH: Vascular niche for adult hippocampal neurogenesis. J Comp Neurol 2000, 425:479-494

27. Iacoangeli M, Di Rienzo A, Colasanti R, Zizzi A, Gladi M, Alvaro L, Nocchi N, Di Somma LG, Scarpelli M, Scerrati M: Endoscopyverified occult subependymal dissemination of glioblastoma and brain metastasis undetected by MRI: prognostic significance. Onco Targets Ther 2012, 5:449-456

28. Willard N, Kleinschmidt-DeMasters BK: Massive dissemination of adult glioblastomas. Clin Neuropathol 2015, 34:330-342

29. Tamura M, Ohye C, Nakazato Y: Pathological anatomy of autopsy brain with malignant glioma. Neurol Med Chir (Tokyo) 1993, 33:77-80

30. Lim DA, Cha S, Mayo MC, Chen MH, Keles E, VandenBerg S, Berger MS: Relationship of glioblastoma multiforme to neural stem cell regions predicts invasive and multifocal tumor phenotype. Neuro Oncol 2007, 9:424-429

31. Radbruch A, Lutz K, Wiestler B, Baumer P, Heiland S, Wick W, Bendszus M: Relevance of T2 signal changes in the assessment of progression of glioblastoma according to the Response Assessment in Neurooncology criteria. Neuro Oncol 2012, 14:222-229

32. Liu S, Wang Y, Fan X, Ma J, Ma W, Wang R, Jiang T: Anatomical involvement of the subventricular zone predicts poor survival outcome in low-grade astrocytomas. PLoS One 2016, 11:e0154539

33. Piccirillo SG, Spiteri I, Sottoriva A, Touloumis A, Ber S, Price SJ, Heywood R, Francis NJ, Howarth KD, Collins VP, Venkitaraman AR, Curtis C, Marioni JC, Tavare S, Watts C: Contributions to drug resistance in glioblastoma derived from malignant cells in the sub-ependymal zone. Cancer Res 2015, 75:194-202

34. Caretti V, Bugiani M, Freret $M$, Schellen $P$, Jansen $M$, van Vuurden D, Kaspers G, Fisher PG, Hulleman E, Wesseling P, 
Vogel H, Monje M: Subventricular spread of diffuse intrinsic pontine glioma. Acta Neuropathol 2014, 128:605-607

35. Lai A, Kharbanda S, Pope WB, Tran A, Solis OE, Peale F, Forrest WF, Pujara K, Carrillo JA, Pandita A, Ellingson BM, Bowers CW, Soriano RH, Schmidt NO, Mohan S, Yong WH, Seshagiri S, Modrusan Z, Jiang Z, Aldape KD, Mischel PS, Liau LM, Escovedo CJ, Chen W, Nghiemphu PL, James CD, Prados MD, Westphal M, Lamszus K, Cloughesy T, Phillips HS: Evidence for sequenced molecular evolution of IDH1 mutant glioblastoma from a distinct cell of origin. J Clin Oncol 2011, 29:4482-4490

36. Mistry AM, Dewan MC, White-Dzuro GA, Brinson PR, Weaver KD, Thompson RC, Ihrie RA, Chambless LB: Decreased survival in glioblastomas is specific to contact with the ventricular-subventricular zone, not subgranular zone or corpus callosum. J Neurooncol 2017, 132:341-349

37. Chen L, Chaichana KL, Kleinberg L, Ye X, Quinones-Hinojosa A, Redmond K: Glioblastoma recurrence patterns near neural stem cell regions. Radiother Oncol 2015, 116:294-300

38. Jafri NF, Clarke JL, Weinberg V, Barani IJ, Cha S: Relationship of glioblastoma multiforme to the subventricular zone is associated with survival. Neuro Oncol 2013, 15:91-96

39. Adeberg S, Konig L, Bostel T, Harrabi S, Welzel T, Debus J, Combs SE: Glioblastoma recurrence patterns after radiation therapy with regard to the subventricular zone. Int J Radiat Oncol Biol Phys 2014, 90:886-893

40. Nestler U, Lutz K, Pichlmeier U, Stummer W, Franz K, Reulen HJ, Bink A; Group ALA Glioma Study: Anatomic features of glioblastoma and their potential impact on survival. Acta Neurochir (Wien) 2015, 157:179-186

41. Sonoda Y, Saito R, Kanamori M, Kumabe T, Uenohara H, Tominaga T: The association of subventricular zone involvement at recurrence with survival after repeat surgery in patients with recurrent glioblastoma. Neurol Med Chir (Tokyo) 2014, 54:302-309

42. Kimura M, Lee Y, Miller R, Castillo M: Glioblastoma multiforme: relationship to subventricular zone and recurrence. Neuroradiol J 2013, 26:542-547

43. Jungk C, Mock A, Exner J, Geisenberger C, Warta R, Capper D, Abdollahi A, Friauf S, Lahrmann B, Grabe N, Beckhove P, von Deimling A, Unterberg A, Herold-Mende C: Spatial transcriptome analysis reveals Notch pathway-associated prognostic markers in IDH1 wild-type glioblastoma involving the subventricular zone. BMC Med 2016, 14:170

44. Siyahhan B, Knobloch V, de Zelicourt D, Asgari M, Schmid Daners M, Poulikakos D, Kurtcuoglu V: Flow induced by ependymal cilia dominates near-wall cerebrospinal fluid dynamics in the lateral ventricles. J R Soc Interface 2014, 11:20131189

45. Ohata S, Alvarez-Buylla A: Planar organization of multiciliated ependymal (E1) cells in the brain ventricular epithelium. Trends Neurosci 2016, 39:543-551

46. Silva-Vargas V, Maldonado-Soto AR, Mizrak D, Codega P, Doetsch F: Age-dependent niche signals from the choroid plexus regulate adult neural stem cells. Cell Stem Cell 2016, 19:643-652

47. Lehtinen MK, Zappaterra MW, Chen X, Yang YJ, Hill AD, Lun M, Maynard T, Gonzalez D, Kim S, Ye P, D'Ercole AJ, Wong ET, LaMantia AS, Walsh CA: The cerebrospinal fluid provides a proliferative niche for neural progenitor cells. Neuron 2011, 69:893-905

48. Thouvenot E, Urbach S, Dantec C, Poncet J, Seveno M, Demettre E, Jouin P, Touchon J, Bockaert J, Marin P: Enhanced detection of CNS cell secretome in plasma protein-depleted cerebrospinal fluid. J Proteome Res 2008, 7:4409-4421

49. Falk A, Frisen J: Amphiregulin is a mitogen for adult neural stem cells. J Neurosci Res 2002, 69:757-762

50. Soroceanu L, Kharbanda S, Chen R, Soriano RH, Aldape K, Misra A, Zha J, Forrest WF, Nigro JM, Modrusan Z, Feuerstein BG, Phillips HS: Identification of IGF2 signaling through phosphoinositide-3-kinase regulatory subunit 3 as a growth-promoting axis in glioblastoma. Proc Natl Acad Sci U S A 2007, 104:3466-3471

51. Yin J, Park G, Kim TH, Hong JH, Kim YJ, Jin X, Kang S, Jung JE, Kim JY, Yun H, Lee JE, Kim M, Chung J, Kim H, Nakano I, Gwak HS, Yoo H, Yoo BC, Kim JH, Hur EM, Lee J, Lee SH,
Park MJ, Park JB: Pigment epithelium-derived factor (PEDF) expression induced by EGFRvIII promotes self-renewal and tumor progression of glioma stem cells. PLoS Biol 2015, 13:e1002152

52. Lorente M, Carracedo A, Torres S, Natali F, Egia A, HernandezTiedra S, Salazar M, Blazquez C, Guzman M, Velasco G: Amphiregulin is a factor for resistance of glioma cells to cannabinoid-induced apoptosis. Glia 2009, 57:1374-1385

53. Chhieng DC, Elgert P, Cohen JM, Jhala NC, Cangiarella JF: Cytology of primary central nervous system neoplasms in cerebrospinal fluid specimens. Diagn Cytopathol 2002, 26:209-212

54. Wang Y, Springer S, Zhang M, McMahon KW, Kinde I, Dobbyn L, Ptak J, Brem H, Chaichana K, Gallia GL, Gokaslan ZL, Groves ML, Jallo GI, Lim M, Olivi A, Quinones-Hinojosa A, Rigamonti D, Riggins GJ, Sciubba DM, Weingart JD, Wolinsky JP, Ye X, ObaShinjo SM, Marie SK, Holdhoff M, Agrawal N, Diaz LA Jr, Papadopoulos N, Kinzler KW, Vogelstein B, Bettegowda C: Detection of tumor-derived DNA in cerebrospinal fluid of patients with primary tumors of the brain and spinal cord. Proc Natl Acad Sci U S A 2015, 112:9704-9709

55. Akers JC, Ramakrishnan V, Kim R, Skog J, Nakano I, Pingle S, Kalinina J, Hua W, Kesari S, Mao Y, Breakefield XO, Hochberg FH, Van Meir EG, Carter BS, Chen CC: MiR-21 in the extracellular vesicles (EVs) of cerebrospinal fluid (CSF): a platform for glioblastoma biomarker development. PLoS One 2013, 8:e78115

56. Skog J, Wurdinger T, van Rijn S, Meijer DH, Gainche L, SenaEsteves M, Curry WT Jr, Carter BS, Krichevsky AM, Breakefield XO: Glioblastoma microvesicles transport RNA and proteins that promote tumour growth and provide diagnostic biomarkers. Nat Cell Biol 2008, 10:1470-1476

57. Perry A, Miller CR, Gujrati M, Scheithauer BW, Zambrano SC, Jost SC, Raghavan R, Qian J, Cochran EJ, Huse JT, Holland EC, Burger PC, Rosenblum MK: Malignant gliomas with primitive neuroectodermal tumor-like components: a clinicopathologic and genetic study of 53 cases. Brain Pathol 2009, 19:81-90

58. Lim DA, Tramontin AD, Trevejo JM, Herrera DG, GarciaVerdugo JM, Alvarez-Buylla A: Noggin antagonizes BMP signaling to create a niche for adult neurogenesis. Neuron 2000, 28:713-726

59. Piccirillo SG, Reynolds BA, Zanetti N, Lamorte G, Binda E, Broggi G, Brem H, Olivi A, Dimeco F, Vescovi AL: Bone morphogenetic proteins inhibit the tumorigenic potential of human brain tumour-initiating cells. Nature 2006, 444:761-765

60. Kokovay E, Goderie S, Wang Y, Lotz S, Lin G, Sun Y, Roysam B, Shen Q, Temple S: Adult SVZ lineage cells home to and leave the vascular niche via differential responses to SDF1/CXCR4 signaling. Cell Stem Cell 2010, 7:163-173

61. Goffart N, Kroonen J, Di Valentin E, Dedobbeleer M, Denne A, Martinive P, Rogister B: Adult mouse subventricular zones stimulate glioblastoma stem cells specific invasion through CXCL12/CXCR4 signaling. Neuro Oncol 2015, 17:81-94

62. Soumier A, Banasr M, Kerkerian-Le Goff L, Daszuta A: Region- and phase-dependent effects of 5-HT(1A) and 5-HT(2C) receptor activation on adult neurogenesis. Eur Neuropsychopharmacol 2010, 20:336-345

63. Ihrie RA, Shah JK, Harwell CC, Levine JH, Guinto CD, Lezameta M, Kriegstein AR, Alvarez-Buylla A: Persistent sonic hedgehog signaling in adult brain determines neural stem cell positional identity. Neuron 2011, 71:250-262

64. Paez-Gonzalez P, Asrican B, Rodriguez E, Kuo CT: Identification of distinct $\mathrm{ChAT}(+)$ neurons and activity-dependent control of postnatal SVZ neurogenesis. Nat Neurosci 2014, 17:934-942

65. Venkatesh HS, Johung TB, Caretti V, Noll A, Tang Y, Nagaraja S, Gibson EM, Mount CW, Polepalli J, Mitra SS, Woo PJ, Malenka RC, Vogel H, Bredel M, Mallick P, Monje M: Neuronal activity promotes glioma growth through neuroligin-3 secretion. Cell 2015, 161:803-816

66. Elias LA, Wang DD, Kriegstein AR: Gap junction adhesion is necessary for radial migration in the neocortex. Nature 2007, 448:901-907

67. Kunze A, Congreso MR, Hartmann C, Wallraff-Beck A, Huttmann K, Bedner P, Requardt R, Seifert G, Redecker C, Willecke K, Hofmann A, 
Pfeifer A, Theis M, Steinhauser C: Connexin expression by radial glialike cells is required for neurogenesis in the adult dentate gyrus. Proc Natl Acad Sci U S A 2009, 106:11336-11341

68. Lin JH, Takano T, Cotrina ML, Arcuino G, Kang J, Liu S, Gao Q, Jiang L, Li F, Lichtenberg-Frate H, Haubrich S, Willecke K, Goldman SA, Nedergaard M: Connexin 43 enhances the adhesivity and mediates the invasion of malignant glioma cells. J Neurosci 2002, 22:4302-4311

69. Mercier F, Kitasako JT, Hatton GI: Anatomy of the brain neurogenic zones revisited: fractones and the fibroblast/macrophage network. J Comp Neurol 2002, 451:170-188

70. McClenahan FK, Sharma H, Shan X, Eyermann C, Colognato H: Dystroglycan suppresses notch to regulate stem cell niche structure and function in the developing postnatal subventricular zone. Dev Cell 2016, 38:548-566

71. Shen Q, Wang Y, Kokovay E, Lin G, Chuang SM, Goderie SK, Roysam B, Temple S: Adult SVZ stem cells lie in a vascular niche: a quantitative analysis of niche cell-cell interactions. Cell Stem Cell 2008, 3:289-300

72. Lathia JD, Gallagher J, Heddleston JM, Wang J, Eyler CE, Macswords J, Wu Q, Vasanji A, McLendon RE, Hjelmeland AB, Rich JN: Integrin alpha 6 regulates glioblastoma stem cells. Cell Stem Cell 2010, 6:421-432

73. Tavazoie M, Van der Veken L, Silva-Vargas V, Louissaint M, Colonna L, Zaidi B, Garcia-Verdugo JM, Doetsch F: A specialized vascular niche for adult neural stem cells. Cell Stem Cell 2008, 3:279-288

74. Shen Q, Goderie SK, Jin L, Karanth N, Sun Y, Abramova N, Vincent P, Pumiglia K, Temple S: Endothelial cells stimulate selfrenewal and expand neurogenesis of neural stem cells. Science 2004, 304:1338-1340

75. Andreu-Agullo C, Morante-Redolat JM, Delgado AC, Farinas I: Vascular niche factor PEDF modulates Notch-dependent stemness in the adult subependymal zone. Nat Neurosci 2009, 12:1514-1523

76. Ramirez-Castillejo C, Sanchez-Sanchez F, Andreu-Agullo C, Ferron SR, Aroca-Aguilar JD, Sanchez P, Mira H, Escribano J, Farinas I: Pigment epithelium-derived factor is a niche signal for neural stem cell renewal. Nat Neurosci 2006, 9:331-339

77. Leventhal C, Rafii S, Rafii D, Shahar A, Goldman SA: Endothelial trophic support of neuronal production and recruitment from the adult mammalian subependyma. Mol Cell Neurosci 1999, 13:450-464

78. Jin K, Zhu Y, Sun Y, Mao XO, Xie L, Greenberg DA: Vascular endothelial growth factor (VEGF) stimulates neurogenesis in vitro and in vivo. Proc Natl Acad Sci U S A 2002, 99:11946-11950

79. Crouch EE, Liu C, Silva-Vargas V, Doetsch F: Regional and stagespecific effects of prospectively purified vascular cells on the adult V-SVZ neural stem cell lineage. J Neurosci 2015, 35:4528-4539

80. Ottone C, Krusche B, Whitby A, Clements M, Quadrato G, Pitulescu ME, Adams RH, Parrinello S: Direct cell-cell contact with the vascular niche maintains quiescent neural stem cells. Nat Cell Biol 2014, 16:1045-1056

81. Calabrese C, Poppleton H, Kocak M, Hogg TL, Fuller C, Hamner B, Oh EY, Gaber MW, Finklestein D, Allen M, Frank A, Bayazitov IT, Zakharenko SS, Gajjar A, Davidoff A, Gilbertson RJ: A perivascular niche for brain tumor stem cells. Cancer Cell 2007, 11:69-82

82. Watkins S, Robel S, Kimbrough IF, Robert SM, Ellis-Davies G, Sontheimer H: Disruption of astrocyte-vascular coupling and the bloodbrain barrier by invading glioma cells. Nat Commun 2014, 5:4196

83. Cheng L, Huang Z, Zhou W, Wu Q, Donnola S, Liu JK, Fang X, Sloan AE, Mao Y, Lathia JD, Min W, McLendon RE, Rich JN, Bao S: Glioblastoma stem cells generate vascular pericytes to support vessel function and tumor growth. Cell 2013, 153:139-152

84. Guichet PO, Guelfi S, Teigell M, Hoppe L, Bakalara N, Bauchet L, Duffau H, Lamszus K, Rothhut B, Hugnot JP: Notch1 stimulation induces a vascularization switch with pericyte-like cell differentiation of glioblastoma stem cells. Stem Cells 2015, 33:21-34

85. Bao S, Wu Q, Sathornsumetee S, Hao Y, Li Z, Hjelmeland AB, Shi Q, McLendon RE, Bigner DD, Rich JN: Stem cell-like glioma cells promote tumor angiogenesis through vascular endothelial growth factor. Cancer Res 2006, 66:7843-7848
86. Shiozawa Y, Pedersen EA, Havens AM, Jung Y, Mishra A, Joseph J, Kim JK, Patel LR, Ying C, Ziegler AM, Pienta MJ, Song J, Wang J, Loberg RD, Krebsbach PH, Pienta KJ, Taichman RS: Human prostate cancer metastases target the hematopoietic stem cell niche to establish footholds in mouse bone marrow. J Clin Invest 2011, 121:1298-1312

87. Kroonen J, Nassen J, Boulanger YG, Provenzano F, Capraro V, Bours V, Martin D, Deprez M, Robe P, Rogister B: Human glioblastoma-initiating cells invade specifically the subventricular zones and olfactory bulbs of mice after striatal injection. Int J Cancer 2011, 129:574-585

88. Goffart N, Lombard A, Lallemand F, Kroonen J, Nassen J, Di Valentin E, Berendsen S, Dedobbeleer M, Willems E, Robe P, Bours V, Martin D, Martinive P, Maquet P, Rogister B: CXCL12 mediates glioblastoma resistance to radiotherapy in the subventricular zone. Neuro Oncol 2017, 19:66-77

89. Qin EY, Cooper DD, Abbott KL, Lennon J, Nagaraja S, Mackay A, Jones C, Vogel H, Jackson PK, Monje M: Neural precursor-derived pleiotrophin mediates subventricular zone invasion by glioma. Cell 2017, 170:845-859.e19

90. Stummer W, Stocker S, Wagner S, Stepp H, Fritsch C, Goetz C, Goetz AE, Kiefmann R, Reulen HJ: Intraoperative detection of malignant gliomas by 5 -aminolevulinic acid-induced porphyrin fluorescence. Neurosurgery 1998, 42:518-525. discussion 525-526

91. Verhaak RG, Hoadley KA, Purdom E, Wang V, Qi Y, Wilkerson MD, Miller CR, Ding L, Golub T, Mesirov JP, Alexe G, Lawrence M, O'Kelly M, Tamayo P, Weir BA, Gabriel S, Winckler W, Gupta S, Jakkula L, Feiler HS, Hodgson JG, James CD, Sarkaria JN, Brennan C, Kahn A, Spellman PT, Wilson RK, Speed TP, Gray JW, Meyerson M, Getz G, Perou CM, Hayes DN; Cancer Genome Atlas Research Network: Integrated genomic analysis identifies clinically relevant subtypes of glioblastoma characterized by abnormalities in PDGFRA, IDH1, EGFR, and NF1. Cancer Cell 2010, 17:98-110

92. Nourallah B, Digpal R, Jena R, Watts C: Irradiating the subventricular zone in glioblastoma patients: is there a case for a clinical trial? Clin Oncol (R Coll Radiol) 2017, 29:26-33

93. Achari R, Arunsingh M, Badgami RK, Saha A, Chatterjee S, Shrimali RK, Mallick I, Arun B: High-dose neural stem cell radiation may not improve survival in glioblastoma. Clin Oncol (R Coll Radiol) 2017, 29:335-343

94. Panagiotakos G, Alshamy G, Chan B, Abrams R, Greenberg E, Saxena A, Bradbury M, Edgar M, Gutin P, Tabar V: Long-term impact of radiation on the stem cell and oligodendrocyte precursors in the brain. PLoS One 2007, 2:e588

95. Achanta P, Capilla-Gonzalez V, Purger D, Reyes J, Sailor K, Song H, Garcia-Verdugo JM, Gonzalez-Perez O, Ford E, QuinonesHinojosa A: Subventricular zone localized irradiation affects the generation of proliferating neural precursor cells and the migration of neuroblasts. Stem Cells 2012, 30:2548-2560

96. Iuchi T, Hatano K, Kodama T, Sakaida T, Yokoi S, Kawasaki K, Hasegawa Y, Hara R: Phase 2 trial of hypofractionated high-dose intensity modulated radiation therapy with concurrent and adjuvant temozolomide for newly diagnosed glioblastoma. Int J Radiat Oncol Biol Phys 2014, 88:793-800

97. Malik M, Akram KS, Joseph D, Valiyaveettil D, Ahmed SF: Prospective study of irradiation of potential stem cell niches in glioblastoma. Int J Radiat Oncol Biol Phys 2015, 93:S111

98. Jeon JY, An JH, Kim SU, Park HG, Lee MA: Migration of human neural stem cells toward an intracranial glioma. Exp Mol Med 2008, 40:84-91

99. Kim SK, Kim SU, Park IH, Bang JH, Aboody KS, Wang KC, Cho BK, Kim M, Menon LG, Black PM, Carroll RS: Human neural stem cells target experimental intracranial medulloblastoma and deliver a therapeutic gene leading to tumor regression. Clin Cancer Res 2006, 12:5550-5556

100. Staflin K, Lindvall M, Zuchner T, Lundberg C: Instructive cross-talk between neural progenitor cells and gliomas. J Neurosci Res 2007, $85: 2147-2159$

101. Liu S, Yin F, Zhao M, Zhou C, Ren J, Huang Q, Zhao Z, Mitra R, Fan W, Fan M: The homing and inhibiting effects of hNSCs-BMP4 on human glioma stem cells. Oncotarget 2016, 7:17920-17931 
102. Bago JR, Okolie O, Dumitru R, Ewend MG, Parker JS, Werff RV, Underhill TM, Schmid RS, Miller CR, Hingtgen SD: Tumor-homing cytotoxic human induced neural stem cells for cancer therapy. Sci Transl Med 2017, 9: eaah6510

103. Shah K, Bureau E, Kim DE, Yang K, Tang Y, Weissleder R, Breakefield XO: Glioma therapy and real-time imaging of neural precursor cell migration and tumor regression. Ann Neurol 2005, 57:34-41

104. Aboody KS, Najbauer J, Metz MZ, D’Apuzzo M, Gutova M, Annala AJ, Synold TW, Couture LA, Blanchard S, Moats RA, Garcia E, Aramburo S, Valenzuela VV, Frank RT, Barish ME, Brown CE, Kim SU, Badie B, Portnow J: Neural stem cell-mediated enzyme/prodrug therapy for glioma: preclinical studies. Sci Transl Med 2013, 5:184ra59

105. Hingtgen SD, Kasmieh R, van de Water J, Weissleder R, Shah K: A novel molecule integrating therapeutic and diagnostic activities reveals multiple aspects of stem cell-based therapy. Stem Cells 2010, 28:832-841

106. Fuentealba LC, Rompani SB, Parraguez JI, Obernier K, Romero R, Cepko CL, Alvarez-Buylla A: Embryonic origin of postnatal neural stem cells. Cell 2015, 161:1644-1655

107. Llorens-Bobadilla E, Zhao S, Baser A, Saiz-Castro G, Zwadlo K, Martin-Villalba A: Single-cell transcriptomics reveals a population of dormant neural stem cells that become activated upon brain injury. Cell Stem Cell 2015, 17:329-340

108. Merkle FT, Mirzadeh Z, Alvarez-Buylla A: Mosaic organization of neural stem cells in the adult brain. Science 2007, 317:381-384
109. Kelsch W, Mosley CP, Lin CW, Lois C: Distinct mammalian precursors are committed to generate neurons with defined dendritic projection patterns. PLoS Biol 2007, 5:e300

110. Young KM, Fogarty M, Kessaris N, Richardson WD: Subventricular zone stem cells are heterogeneous with respect to their embryonic origins and neurogenic fates in the adult olfactory bulb. J Neurosci 2007, 27:8286-8296

111. Solano Fonseca R, Mahesula S, Apple DM, Raghunathan R, Dugan A, Cardona A, O’Connor J, Kokovay E: Neurogenic niche microglia undergo positional remodeling and progressive activation contributing to age-associated reductions in neurogenesis. Stem Cells Dev 2016, 25:542-555

112. Leelatian N, Doxie DB, Greenplate AR, Mobley BC, Lehman JM, Sinnaeve J, Kauffmann RM, Werkhaven JA, Mistry AM, Weaver KD, Thompson RC, Massion PP, Hooks MA, Kelley MC, Chambless LB, Ihrie RA, Irish JM: Single cell analysis of human tissues and solid tumors with mass cytometry. Cytometry B Clin Cytom 2017, 92:68-78

113. Wei W, Shin YS, Xue M, Matsutani T, Masui K, Yang H, Ikegami S, Gu Y, Herrmann K, Johnson D, Ding X, Hwang K, Kim J, Zhou J, Su Y, Li X, Bonetti B, Chopra R, James CD, Cavenee WK, Cloughesy TF, Mischel PS, Heath JR, Gini B: Single-cell phosphoproteomics resolves adaptive signaling dynamics and informs targeted combination therapy in glioblastoma. Cancer Cell 2016, 29: $563-573$ 